\title{
Sustainability Indicators in Solid Waste Management: A Case Study in a Developing Country
}

\author{
Cecilia de Mattos Canella ${ }^{1}$, Fernanda Bento Rosa Gomes ${ }^{2} \&$ Samuel Rodrigues Castro ${ }^{1,2,3}$ \\ ${ }^{1}$ Postgraduate Program in Constructed Environment, Federal University of Juiz de Fora (UFJF), Juiz de Fora, MG, \\ Minas Gerais, Brazil \\ ${ }^{2}$ Postgraduate Program in Civil Engineering, Federal University of Juiz de Fora (UFJF), Juiz de Fora, Minas \\ Gerais, Brazil \\ ${ }^{3}$ Department of Environmental and Sanitary Engineering, Federal University of Juiz de Fora (UFJF), Juiz de Fora, \\ Minas Gerais, Brazil
}

Correspondence: Samuel Rodrigues Castro, Federal University of Juiz de Fora (UFJF), Juiz de Fora, MG, 36036330, Brazil. E-mail: samuel.castro@ufjf.edu.br

Received: August 12, 2021

doi:10.5539/jsd.v14n5p74
Accepted: September 5, 2021

Online Published: September 6, 2021

URL: https://doi.org/10.5539/jsd.v14n5p74

\begin{abstract}
The generation of municipal solid waste (MSW) has been crescent. Due to this, there is a growing concern about MSW disposal. Whitin a scenario of limited financial resources, the management of MSW may be a challenge for Brazilian municipalities. Indicators can be effective instruments for assessing MSW management, as well as local socioeconomic and socio-environmental aspects. Thus, this work aimed at characterizing the MSW management in regions of the Brazilian state of Minas Gerais through an analysis of socioeconomic and sustainability indicators, considering the 10 years since the Brazilian National Solid Waste Policy. For this purpose, indicators of MSW management and socioeconomic development of municipalities of Minas Gerais were analyzed. The statistical analysis evidenced some characteristics reported in literature. Furthermore, MSW management indicators were not directly related to the available data on basic sanitation in the territories. Results also evidenced a lack of financial and economic sustainability of MSW management in the municipalities.
\end{abstract}

Keywords: Brazil, Minas Gerais, statistical analysis, socioeconomic development, basic sanitation, Brazilian National Solid Waste Policy

\section{Introduction}

Population growth and urbanization have been intensified the generation of Municipal Solid Waste (MSW) and, consequently, the demand for environmentally correct disposal solutions. Given the diversity of realities and the lack of financial resources, support tools, or capable workers, Brazilian municipalities face many difficulties in managing their MSW (Lima et al., 2017).

The concept of MSW management, created in the 1990s, includes planning and operation practices of MSW management systems from social, technical, and operational perspectives. Regarding the social dimension, the attribution of the different actors involved in management may be assessed from a socio-economic and socioenvironmental perspective. In this sense, environmental education is a fundamental tool, which allows the valuation of the work of MSW collection workers and help population to build a better understanding of their responsibility in MSW management (Sabedot \& Pereira Neto, 2017).

In this context, in 2010, the Brazilian National Solid Waste Policy (PNRS) was created, establishing principles, objectives, guidelines, instruments, goals, and actions for the management of MSW. The waste plans proposed in the PNRS establishes actions and targets for waste management at national, state and municipal levels. These actions includes i) eradicating of dumps; ii) requirement of waste management plans for private companies; iii) implementation of selective collection and reverse logistics; iv) promoting non-generation, reduction, reuse, recycling, and treatment of solid waste and ensuring the environmentally correct final disposal of waste; v) development and adoption of clean technologies to minimize environmental impacts; vi) technical and financial cooperation between public management and business sector; vii) training of workers and technical staff; viii) universalization of public services for solid waste management and urban cleaning; ix) promoting life cycle 
assessments; and $\mathrm{x}$ ) encouragement to sustainable consumption (Brasil, 2010)

MSW management includes generation, conditioning, collection, transport, transfer, treatment, and final disposal. MSW generation varies with socioeconomic and regional conditions, as well as the proportion of organic and recyclable wastes. In 2018, the average generation per capita in Brazil was $1.039 \mathrm{~kg} /$ day, representing a total of 79 million tonnes (Abrelpe, 2019). The annual monitoring of waste generation can also be an indication of improvement of country's economic conditions, since the amount waste generated may be related to the population's purchasing power.

According to Santiago \& Dias (2012), environmental indicators may be an important tool for evaluating and monitoring MSW management. They may attest the sustainability degree of the management model and guide plans and strategies for further improvements. Furthermore, indicators are an intelligible way to inform the population about statistical, scientific, and technical data. Fernandes et al. (2012) argue that socio-environmental planning based on sustainability indicators not only enables partnerships between government and society, but also promotes trust, dynamism, and visibility to the data studied.

Thus, this work aimed at characterizing the management of MSW in the Brazilian state of Minas Gerais, through an analysis of socioeconomic and sustainability indicators, considering a legal and regulatory framework of the 10 years of the PNRS.

\section{Method}

\subsection{Study Area}

This work had the Brazilian state of Minas Gerais as its study area. As established by the Secretariat of Planning and Management (SEPLAG), municipalities of Minas Gerais are divided into Development Territories. This division has been valid since 2015 and it is based on social, economic, and territorial characteristics. Figure 1 shows the 17 Development Territories of Minas Gerais: Alto Jequitinhonha, Caparaó, Central, Mata, Médio e Baixo Jequitinhonha, Metropolitano, Mucuri, Noroeste, Norte, Oeste, Sudoeste, Sul, Triângulo Norte, Triângulo Sul, Vale do Aço, Vale do Rio Doce, and Vertentes (Seplag, 2015).

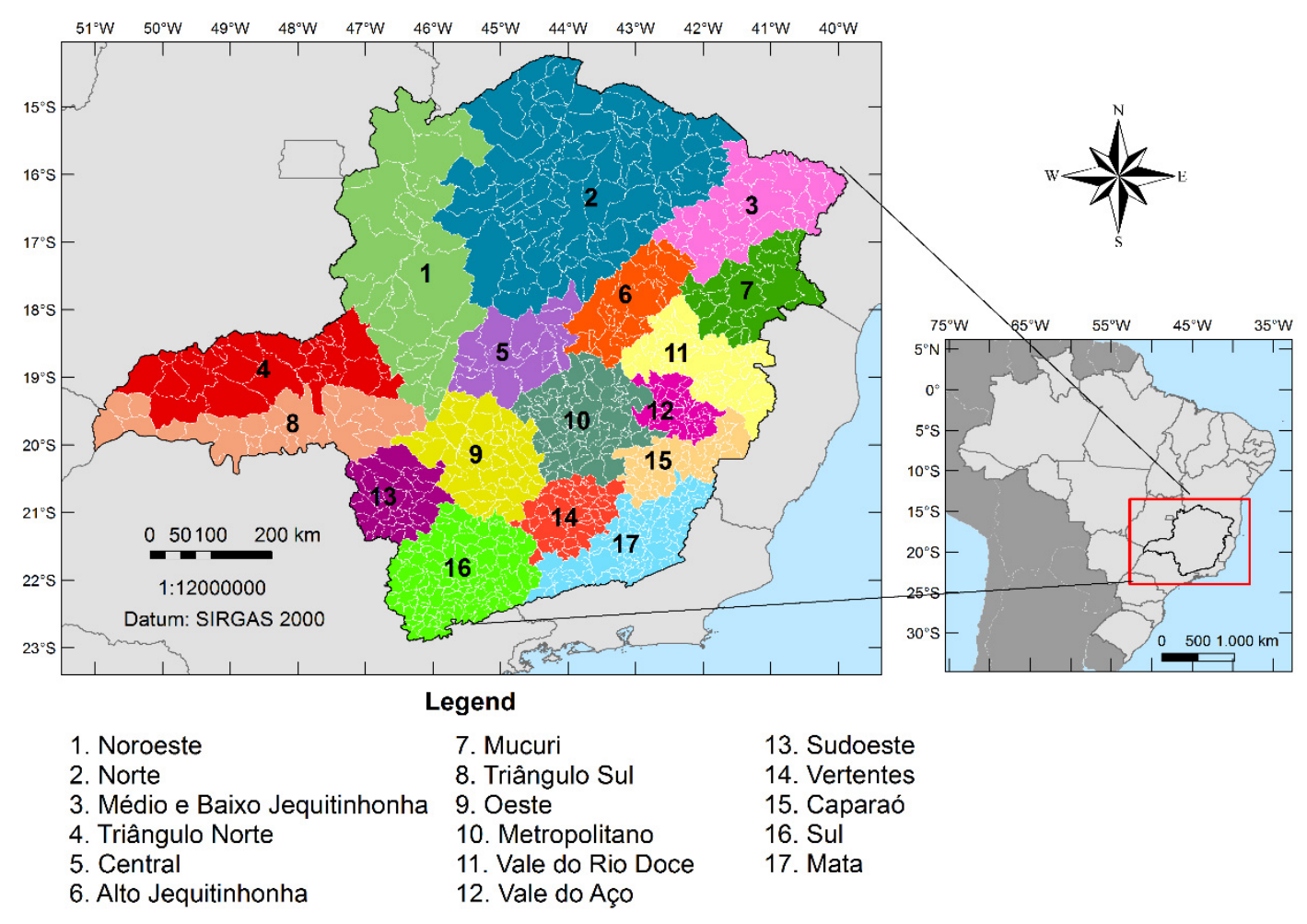

Figure 1. Development territories of Minas Gerais

\subsection{Data Collection}

Data regarding the indicators shown in Table 1 were collected considering the period from 2009 to 2018 . This 
period was chosen in order to analyze the evolution of MSW management considering the 10 years of enactment of the PNRS.

The selection of indicators was made prioritizing national indicators or those adapted for the Brazilian reality, aiming to consider regionalities and socioeconomic and environmental aspects of MSW management. Thus, indicators already consolidated in Brazil and which were applied for the studied municipalities between 2009 and 2018 were selected.

IFDM was created in 2005 by the Federation of Industries of the State of Rio de Janeiro (Firjan). It assesses socioeconomic development in the Brazil through three main pillars: i) employment and income, ii) education, and iii) health. IFGF was created in 2012 by Firjan and it aims to assess the efficiency of fiscal management, focusing on the administration of public resources by municipalities. ISLU was created in 2016 by the National Union of Urban Cleaning Companies, and its main objective is to define how much each municipality complies with the PNRS through urban cleaning and actions of MSW management. Indicators IN006, IN011, IN016, IN023, and IN031 are provided by Brazilian National Sanitation Information System (SNIS). The SNIS gathers indicators on the four areas of basic sanitation provided in Brazil: water and sewage services, MSW management, and urban drainage. In 2018, 47 indicators for MSW were provided by SNIS, comprising data from 3,468 municipalities, which corresponds to $85.6 \%$ of the Brazilian urban population (Snis, 2019).

Table 1. Indicators selected in this work

\begin{tabular}{|c|c|c|}
\hline Indicator & Description & Source \\
\hline IFDM & FIRJAN Municipal Development Index & Firjan (2020a) \\
\hline IFGF & FIRJAN Tax Management Index & Firjan $(2020 b)$ \\
\hline ISLU & Sustainability and Urban Cleaning Index & Selur (2020) \\
\hline IN006 & $\begin{array}{l}\text { Cost per capita in MSW management in relation to the urban population } \\
\text { (R\$/inhabitant) }\end{array}$ & Snis (2020) \\
\hline IN011 & $\begin{array}{l}\text { Revenue collected per capita through fees or other forms of charging for } \\
\text { MSW management services (R } \$ \text { /inhabitant) }\end{array}$ & Snis (2020) \\
\hline IN016 & $\begin{array}{l}\text { Rate of the coverage of MSW collection service in relation to the urban } \\
\text { population }(\%)\end{array}$ & Snis (2020) \\
\hline IN023 & Average unit cost of MSW collection service $(\mathrm{R} \$ / \mathrm{t})$ & Snis (2020) \\
\hline IN031 & $\begin{array}{l}\text { Rate of recovery of recyclable materials in relation to the total amount } \\
\text { collected (\%) }\end{array}$ & Snis (2020) \\
\hline
\end{tabular}

Data about MSW disposal in municipalities were obtained from the State Environmental Foundation (Feam, 2019). Municipalities that employ an environmentally correct MSW disposal (through sanitary landfills or sorting and composting units) were initially selected. After analyzing the municipalities that have an environmentally correct MSW disposal, a second selection was made. During this step, municipalities that did not had data for the selected indicators for at least one year between 2009 and 2018 were excluded. The purpose of this filter was to define a consistent dataset for the statistical analyses. Thus, data from 84 municipalities were selected for the analyses. Consequently, some Development Territories could not be included in the analysis. Thus, the assessment of MSW management carried out in this work comprised the following Development Territories: Mata (17), Metropolitano (10), Triângulo Sul (8), Vertentes (14), Triângulo Norte (4), Sul (16), Caparaó (15), and Noroeste (1) (Figure 1).

Additionally, data on the coverage of water supply and sewage collection services in the selected territories were obtained (Trata Brasil, 2020). Data regarding the territories' Gross Domestic Product (GDP) and the portion of the population in poverty were also collected (Seplag, 2015).

\subsection{Data Analysis}

The Shapiro-Wilk test at $95 \%$ confidence level carried out to check if the data fits the normal distribution. As most of data series had a non-normal distribution, the median was defined as a reference measure of central tendency for comparing MSW management in the different development territories of Minas Gerais, according to Zaros \& Medeiros (2011). 


\subsubsection{Panel Data Analysis}

Panel data analysis consists of a regression model, in which data vary in spatial and temporal dimensions. Panel data analysis is more suitable for analyzing the dynamics of variables changing in addition to admitting more complex behavioral models than simple linear regression models (Gujarati \& Porter, 2011). Thus, panel analysis was used in the study to analyze the level of dependence between sustainability indicators and specific indicators of MSW management, as shown in Equations 1,2 and 3.

$$
\begin{aligned}
& I F G F=\beta_{0}+\beta_{1} I N 006+\beta_{2} I N 011 \\
& I N 011=\beta_{0}+\beta_{1} I N 006+\beta_{2} I N 023 \\
& I N 031=\beta_{0}+\beta_{1} I F D M+\beta_{2} I F G F
\end{aligned}
$$

Equation 1 has the IFGF index as a dependent variable and the indicators IN006 and IN011, aiming at verifying the degree of dependence between the fiscal management of the municipalities (IFGF) and the cost (IN006) and revenue (IN011) collected for the MSW management. This equation was based on the hypothesis of the existence of dependence on the sustainable fiscal management of a municipality with the cost and revenue collected from the management of MSW.

In Equation 2, the dependent variable is IN011 and the independent variables are IN006 and IN023. The initial hypothesis is there is a degree of dependence between the revenue collected (IN011) and the costs associated with the management of MSW (costs of MSW collection services - IN023 - and cost with MSW management - IN006).

Finally, the model proposed in Equation 3 aims to verify if there is a dependence between the recyclables recovery rate (IN031) and the municipal development (IFDM) and fiscal management (IFGF) of the municipalities. This equation analyzes the initial hypothesis that the management of MSW becomes more effective with the development of a municipality, increasing the percentage of recyclable waste recovery.

For the panel analysis, data from each municipality of the selected development territories were considered, aiming to compute the spatial variability also within the territories. The assumptions of panel data regression models were analyzed at $95 \%$ confidence level. Variance inflation factors for each variable were computed and the presence of multicollinearity between variables was verified. Furthermore, the presence of omitted variables, homoscedasticity, and autocorrelation in the models were also assessed. Panel data analysis was performed using Stata Version 12 software.

\section{Results and Discussion}

The National Solid Waste Policy (PNRS) is the main regulatory framework for waste management in Brazil, in which several guidelines and goals for a sustainable MSW management were established. One of the main goals of the PNRS is promoting an adequate disposal of refuses, which includes eradicating dumps and controlled landfills. In this context, environmentally correct MSW disposal in Brazil has shown progress over the years since the creation of the PNRS (Figure 2). However, as it can be seen, it is far from the minimum percentage of $95 \%$ from which it can be considered a universal service.

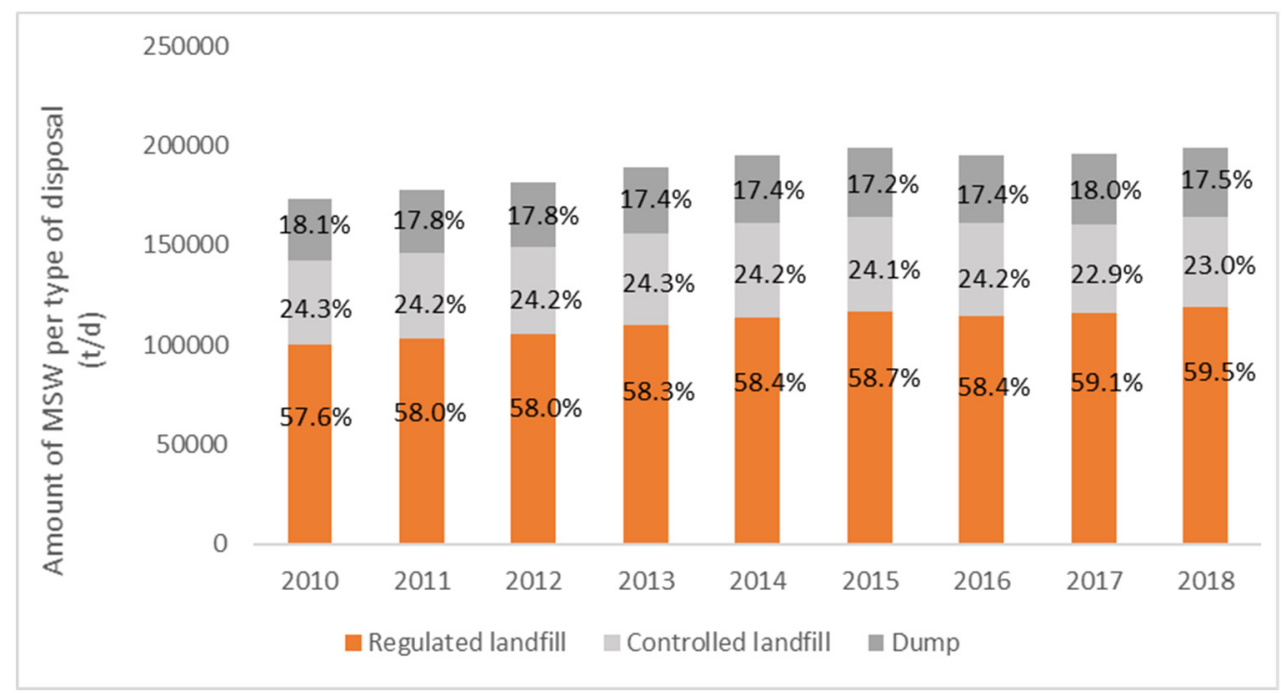

Figure 2. Destination of municipal solid waste (MSW) collected in Brazil from 2010 to 2017 
In 2019, the state of Minas Gerais had 21,168,791 inhabitants in a territory of 586,521,123 km² (Ibge, 2020). Minas Gerais is the state with the largest number of municipalities in Brazil, comprising an amount of 853 municipalities, which represents more than $15 \%$ of the Brazilian municipalities. Minas Gerais is also the fourth largest Brazilian state and has the second largest population of Brazil (Ibge, 2020). In 2010, the human development index (HDI) of Minas Gerais was 0.731, whereas Brazil's HDI was 0.724 (Ibge, 2020). Furthermore, the monthly household income per capita in Brazil in 2020 was about 260 USD, while in Minas Gerais, it was about 250 USD (Ibge, 2020). Due to these aspects, Minas Gerais can greatly represent the Brazilian reality.

In terms of MSW management, in 2018, 46.1\% of the Brazilian municipalities had an environmentally correct MSW final disposal service (Brasil, 2020a). At this same time, $45.8 \%$ of the total of Minas Gerais' municipalities (392 municipalities) disposed their MSW in sanitary landfills and/or regulated sorting and composting units, covering $61.87 \%$ of the urban population. MSW disposal are made by regulated landfilling in 289 municipalities. On the other hand, MSW are destinated for sorting and composting units in 130 municipalities. Moreover, 27 municipalities are served by both landfills and sorting and composting units (Figure 3). Regarding the irregular MSW disposal, $25.28 \%$ of municipalities dispose their waste in controlled landfills or dumps, whereas $12.85 \%$ dispose in irregular landfills or sorting and composting units (Feam, 2019).

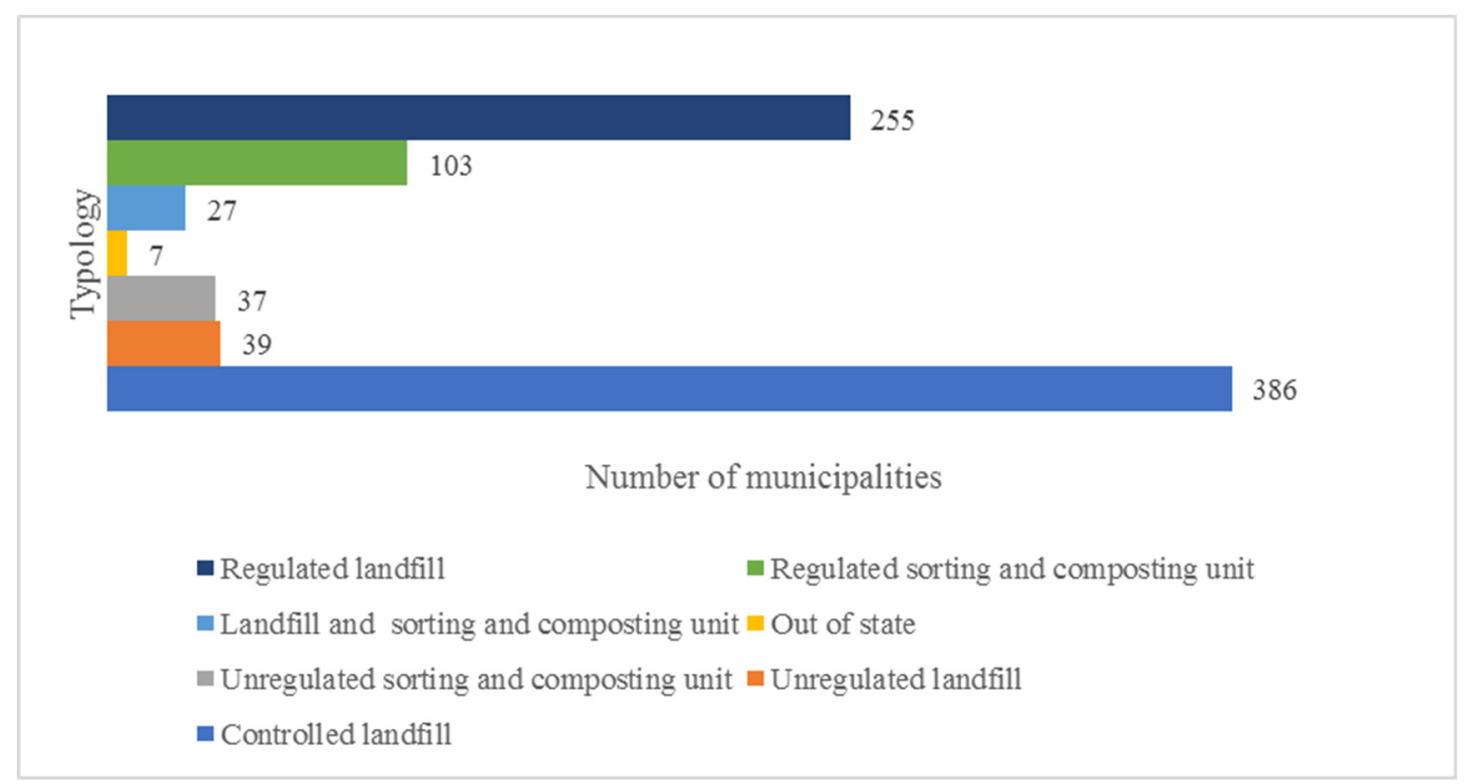

Figure 3. Destination of municipal solid waste (MSW) in Minas Gerais in 2018. Number of municipalities by type of destination

Data regarding socioeconomic and environmental characteristics and indicators of the development territories are shown in Table 2. Values expressed in Table 2 and the map of Development Territories (Figure 1) show that socioeconomic variability are spatially concentrated. Territories further North and far from the large centers concentrate the largest portion of the population in poverty. For example, Alto Jequitinhonha, Médio e Baixo Jequitinhonha, and Mucuri had the largest proportions of population in poverty and they are located in the Northeast region of the state of Minas Gerais. Meanwhile, the Metropolitano territory, where Belo Horizonte (capital of Minas Gerais) is located, had the highest population density and the third lowest concentration of population in poverty in the state. Triângulo Sul had the lowest concentration of population in poverty, followed by Triângulo Norte, both located at the opposite end of the poorest development territories of the state of Minas Gerais. The favorable economic situation of these two development territories may be explained by the fact that they concentrate six industrial centers, having the largest agricultural production in the state of Minas Gerais, in addition to having a strong tourist appeal (Seplag, 2015). Socioeconomic aspects guide the geographic and spatial dimensions. In a more comprehensive analysis, it is possible to compare this same socioeconomic information with the heterogeneity of basic sanitation services.

In $2018,83.62 \%$ of the Brazilian population had access to the drinking water supply networks, whereas $53 \%$ were served with sewage collection networks (Trata Brasil, 2020) and 92.1\% with collection of MSW. Furthermore, $75.6 \%$ of the Brazilian population that had access to MSW collection services had an appropriate MSW disposal 
(Snis, 2019). It is plausible to say that the same territories that have the best socioeconomic conditions have access to basic sanitation services in better conditions than the national average. On the other hand, territories with the worst socioeconomic conditions have worse indicators than the national average. In the latter case, there are even worrying scenarios, such as the case of Alto Jequitinhonha and Médio e Baixo Jequitinhonha. Less than $70 \%$ of the population of these territories had access to drinking water supply services, and less than $10 \%$ of the population is served with an environmentally correct MSW disposal, a fact that may represent a risk to the population health.

IFDM and IFGF are indicators of municipal development and fiscal management, respectively. The territories that had the highest medians of IFDM and IFGF were Caparaó ( 0.7741 and 0.7556 , respectively), Noroeste $(0.7525$ and 0.6407 , respectively), Triângulo Norte (0.7522 and 0.6147 , respectively), and Triângulo Sul (0.7528 and 0.5941 , respectively), while the territory Vertentes had the second lowest median for both indicators (IFDM $=$ 0.7244 and IFGF $=0.4163$ ). These data reaffirm the high development rates of Triângulo Sul and Triangulo Norte territories, which had high Gross Domestic Products (GDP) (5.5\% and 9.0\% respectively), and low proportion of population in poverty $(23.8 \%$ and $240.0 \%$ respectively).

Table 2. Indicators and characteristics of Minas Gerais' development territories

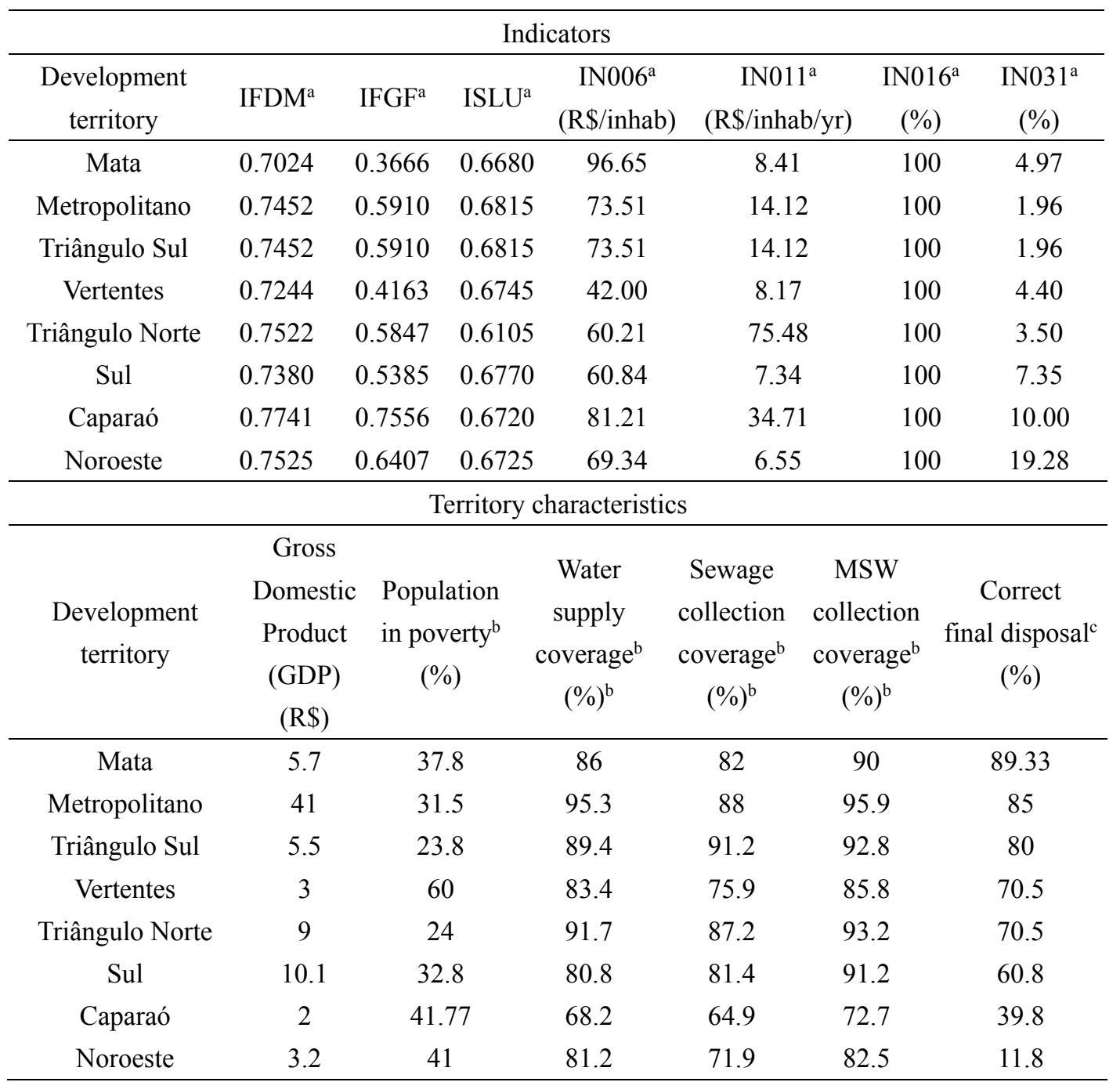

Note. a: see Table 1; b: Percentage of population; c: Percentage of population served by an environmentally correct solution for MSW disposal according to the Brazilian National Solid Waste Policy (PNRS) (sanitary landfills or sorting and composting units).

However, these indicators do not support the same information for Mata and Caparaó territories. Mata had a higher GDP $(5.7 \%)$ and lower concentration of population in poverty $(37.8 \%)$ than Vertentes $(3.0 \%$ and $60.0 \%$, 
respectively) and Noroeste (3.2\% and $41.0 \%$, respectively). However, Vertentes and Noroeste IFDM and IFGF higher than Mata. Furthermore, Caparaó had the highest medians for IFDM and IFGF indicators $(0.7741$ and 0.7556). However, Caparaó had a GDP that corresponds to $2.0 \%$ of the total of Minas Gerais and the concentration of population in poverty represented $41.77 \%$ of its population.

ISLU is an indicator of the sustainability urban cleaning services, which considers socioeconomic data, such as the HDI, tax collection, waste recovery, and the rate of population served by MSW management services. The development territories that had the highest medians for ISLU were Metropolitano (0.6815), Triângulo Sul (0.6815) and Sul (0.6770), respectively, while Triângulo Norte had the lowest median (0.6105). The large medians of ISLU in Metropolitan and Triângulo Sul seem to be supported by the high rate of MSW collection MSW (95.9\% and $92.8 \%$, respectively) and regularized MSW disposal ( $85.0 \%$ and $80.0 \%$, respectively). On the other hand, the ISLU of Triângulo Norte contrasts with the high MSW collection rate (93.2\%), which was the second highest percentage among the territories, and high rate of regularized MSW disposal (70.5\%), which was the fourth highest percentage of regularized waste disposal.

The indicators IN006, IN011, and IN031 represent, respectively, the expense and revenue with MSW management services and the recyclables recovery rate. Triângulo Sul and Metropolitano had the lowest recyclables recovery rates (IN031), contrasting with their ISLU. Caparaó had the second highest values of IN006, IN011, and IN031. Moreover, Noroeste had the second smallest revenue with MSW management services (IN011). However, it had second highest recyclables recovery rate (IN031). Indicators must be analysed together with other information, such as the number of inhabitants, for example, which would justify proportional expenses and revenues. However, in a preliminary analysis, indicators of Caparaó and Noroeste were conflicting, as they had some similar socioeconomic characteristics such as the number of inhabitants and the concentration of population in poverty.

In Caparaó, which had divergent results in previous analyses, the expenditure per capita with MSW management (IN006) increased significantly over the years. In 2009, IN006 was slightly higher than R $\$ 80.00$ /inhabitant. While, in 2018, IN006 was R \$160.00/inhabitant. On the other hand, indicator IN011, which shows the revenue collected, was about $\mathrm{R} \$ 10.00 /$ inhabitant in 2009 and about $\mathrm{R} \$ 50.00 /$ inhabitant in 2018 . When comparing these indicators, it is clear that the value of the revenue collected does not follow the cost. Furthermore, in 2009, the recyclables recovery rate (IN031) was slightly above $20 \%$ and, in 2018 , it dropped to less than $5 \%$.

In the Noroeste, expenditure per capita with MSW management (IN006) ranged around R $\$ 20.00 /$ inhabitant and $\mathrm{R} \$$ 60.00/inhabitant, while the revenue collected for MSW management (IN011) was between R \$2.00/inhabitant, and R \$8.00/inhabitant. However, IN031, varied negatively from 2009 to 2018 , from $30 \%$ to $10 \%$. This fact may be related to socioeconomic indexes, such as the index of population in poverty (41\%), the low GDP (3\%). Moreover, it may also be related with a precariousness in MSW management, which may lead to serious urban problems (Moh \& Malaf, 2014).

The same happened with the Triângulo Sul development territory, which had the IN006 indicator ranging from $\mathrm{R} \$ 20.00 /$ inhabitant to R \$ 100.00/inhabitant, the IN011 varying from R \$5.00/inhabitant to R \$ 60.00/inhabitant, and the IN031 varying negatively from $15 \%$ to $5 \%$ between 2009 and 2018 .

It is important to emphasize that an increase in the cost of MSW management over the years is expected, since it generally follows increases in MSW generation, which is strictly related to the population's purchasing power (Lima et al., 2017). However, it was noticed that the collected revenue and the recyclables recovery rate did not follow the costs with MSW management in most of the development territories of Minas Gerais.

Generally, the recyclables recovery rate is very small compared with the total amount of MSW collected. This fact may be related to the difference between cost and revenue of MSW management, since municipalities do not have a sufficient structure for the collection and treatment of recyclables, resulting in a deficient supply chain (Feitosa et al., 2020).

Results of the panel data analysis are shown in Table 3. The model of Equation 1 has the municipal tax management (IFGF) as a dependent variable and the cost (IN006) and revenue (IN011) for MSW management as independent variables. In this model, a statistically significant relationship between IFGF and IN006 (p-value $<0.05$ ) was evidenced. The coefficient $\beta_{1}$ of Equation 1 evidenced that IN006 negatively influences IFGF, i. e., increasing the expenditure in MSW management negatively affects the tax management in municipalities. No statistically significant relationship between the IFGF and IN011 was evidenced ( $p$-value $=0.203$ ). The charging of tariffs in Brazil is not directly associated with an idea of equivalence, but with the existence of an activity developed in favor of the taxpayer (Ribas \& Pinheiro, 2018). Thus, it is plausible that the revenue for MSW management is not directly and significantly related with tax management. 
The model proposed in Equation 2 has the revenue for MSW management (IN011) as a dependent variable and the costs with MSW management (IN006) and MSW collection services (IN023) as independent variables. As it can be seen, there is no significant relationship between these indicators ( $\mathrm{p}$-value $>0.05$ ). However, the coefficients $\beta_{1}$ and $\beta_{2}$ of Equation 2 show that the revenue for MSW management tends to grow with increasing costs, as expected. This relationship between the indicators is explained through the adoption of fees, tariffs and other public prices charged for urban cleaning and MSW management as essential instruments to promote environmental sustainability, as ratified by Brazilian Federal Law n ${ }^{\circ}$ 14,026/2020 (Brasil, 2020b). Revenues guarantee financial resources for MSW collection and management services as well as for fiscal, by releasing a significant part of municipal resources previously destined to financing these services for other purposes of public interest (Ribas \& Pinheiro, 2018).

Table 3. Summary results of the panel data analysis

\begin{tabular}{cccccc}
\hline & & & $\beta_{0}$ & $\beta_{1}$ & $\beta_{2}$ \\
\hline \multirow{2}{*}{ Equation 1 } & \multirow{2}{*}{ IFGF $=\beta_{0}+\beta_{I} I N 006+\beta_{2} I N 011$} & Coefficient & 0.65 & -0.00095 & -0.00064 \\
& & $\mathrm{p}$-value & $0.000^{\mathrm{a}}$ & $0.005^{\mathrm{a}}$ & 0.203 \\
\multirow{3}{*}{ Equation 2 } & $I N 011=\beta_{0}+\beta_{I} I N 006+\beta_{2} I N 023$ & Coefficient & 13.57 & 0.053 & 0.020 \\
& & $\mathrm{p}$-value & $0.000^{\mathrm{a}}$ & 0.325 & 0.342 \\
& \multirow{3}{*}{ Equation 3 } & Coefficient & -10.75 & 18.40 & 12.07 \\
& & p-value & 0.549 & 0.469 & 0.124 \\
\hline
\end{tabular}

Note. a: statistically significant evidence at $95 \%$ confidence level.

Equation 3 shows the model that had recyclables recovery rate (IN031) as dependent variable and the municipal development (IFDM) and fiscal management (IFGF) as independent variables. These indicators did not show a significant correlation ( $\mathrm{p}$-valor $>0.05$ ). Municipal planning to deal with MSW management is a continuous process, observing the potentialities related to waste recycling (Silva et al., 2017). Thus, it is reasonable to expect that the recyclable recovery rate tends to grow with the municipal development and a sustainable fiscal management, a fact evidenced by the direct relationship between the independent and dependent variables presented by the proposed model.

Results obtained in the panel analysis highlight, especially, the economic aspects that permeate MSW management. Considering that the territories that had the best socioeconomic conditions, have the highest rates of attendance of basic sanitation services, it is reasonable to say that sanitation acts as an indicator of the development of a municipality, since the sanitation helps in understanding social and economic issues (Nguyen-Viet et al., 2009).

\section{Conclusions}

Indicators of municipal solid waste management (MSW) and environmental and socioeconomic development of municipalities of Minas Gerais were analyzed, aiming at assessing MSW management in the 10 years since the Brazilian National Solid Waste Policy (PNRS). As a first step in the statistical analysis, a descriptive analysis was performed to compare the indicators. In this analysis, it was possible to notice that some of the characteristics of territories present in the literature were supported, such as the socioeconomic indicators IFDM (FIRJAN Municipal Development Index), IFGF (FIRJAN Tax Management Index), the values of Gross Domestic Product (GDP), and the proportion of population in poverty. As expected, municipalities that had best socioeconomic conditions generally offer best basic sanitation services, including MSW collection, destination, and disposal services. Unbalanced expenditure and revenue evidenced a worrying situation in terms of financial and economic sustainability of MSW management.

Results obtained through panel data analyses show the association between costs and revenues for MSW management and the municipal fiscal management, showing an association between MSW management and economic indicators. Furthermore, it is worthwhile to mention that MSW is an action of shared responsibility. Population is responsible to properly separating and packaging their waste, whereas and the municipalities are responsible to collect, transport, treat and dispose of these wastes. Although federal agencies generally support local MSW management regulations, there are some divergences in actions, making the solid waste scenario still critical and with a worrying future. 


\section{References}

Abrelpe. Associação Brasileira das Empresas de Limpeza Pública. (2019). Panorama dos Resíduos Sólidos no Brasil 2018/2018. São Paulo: Abrelpe.

Brasil. (2010). Lei $n^{\circ}$ 12.305, de 02 de agosto de 2010. Política Nacional de Resíduos Sólidos. Brasília/DF.

Brasil. (2020a). Plano Nacional De Resíduos Sólidos (Consulta Pública). Brasília/DF: Brasil.

Brasil. (2020b). Lei $n^{o}$ 14.026, de 15 de julho de 2020. Brasília/DF.

Feam. Fundação Estadual do Meio Ambiente. (2019). Panorama da destinação dos resíduos sólidos urbanos no estado de Minas Gerais em 2018. Belo Horizonte: Feam.

Fechine, R., \& Moraes, L. R. S. (2015). Matriz de indicadores de sustentabilidade de coleta seletiva com utilização do Método Delphi. Revista Eletrônica de Engenharia Civil, 10(1), 22-35. https://doi.org/10.5216/reec.v10i1.32721

Feitosa, A. K., Barden, J. E., Konrad, O., \& Matos, M. A. A. (2020). Avaliação da gestão de resíduos sólidos urbanos em um município do Nordeste brasileiro. Journal of Social, Technological and Environmental Science, 9(1), 293-315.

Fernandes, V., Malheiros, T. F., Philippi Jr, A., \& Sampaio, C. A. C. (2012). Metodologia de Avaliação Estratégica de Processo de Gestão Ambiental Municipal. Saúde e Sociedade, 21(supl.3), 128-143. https://doi.org/10.1590/S0104-12902012000700011

Firjan. Federação das Indústrias do Estado do Rio de Janeiro. (2020a). Índice Firjan de desenvolvimento municipal - IFDM. Retrieved from https://www.firjan.com.br/ifdm/

Firjan. Federação das Indústrias do Estado do Rio de Janeiro. (2020b). Índice Firjan de gestão fiscal - IFGF. Retrieved from https://www.firjan.com.br/ifgf/

Gujarati, D. N., \& Porter, D. C. (2011). Econometria Básica (5th ed). Porto Alegre: AMGH Editora Ltda.

Ibam. Instituto Brasileiro de Administração Municipal. (2001). Manual Gerenciamento Integrado de Resíduos Sólidos. Rio de Janeiro: Ibam.

Ibge. Instituto Brasileiro de Geografia e Estatística. (2020). Minas Gerais. Retrieved from https://cidades.ibge.gov.br/brasil/mg/panorama

Instituto Trata Brasil. (2020). Ranking do saneamento. Retrieved from http://www.tratabrasil.org.br/images/estudos/itb/ranking_2020/Relatorio_Ranking_Trata_Brasil_2020_Julh o_.pdf.

Lima, J. R., Santos, E. L. N., \& Medeiros, J. P. (2017). Saneamento e saúde pública: análise das relações entre indicadores no estado do Rio Grande do Norte. Revista Metropolitana de Sustentabilidade, 7(2), 134-151.

Moh, Y. C., \& Manaf, L. A. (2014). Overview of household solid waste recycling policy status and challenges in Malaysia. Resources, Conservation and Recycling, 82, https://doi.org/10.1016/j.resconrec.2013.11.004

Nguyen-Viet. H., Zinsstag. J., Schertenleib. R., Zurbrugg. C., Obrist, B., Montangero, A., Surkinku, N., Kone, D., Morel, A., Cisse, G., Koottatep, T., Bonfoh, B., \& Tanner, M. (2009). Improving environmental sanitation, health, and well-being a conceptual framework for integral interventions. EcoHealth, 6, 180-191. https://doi.org/10.1007/s10393-009-0249-6

Ribas, L. M., \& Pinheiro, H. (2019). Taxa de resíduos sólidos como instrumento para promoção do direito fundamental ao meio ambiente equilibrado. Revista Direito Economia Socioambiental, 10(2), 233-260. https://dx.doi.org/10.7213/rev.dir.econ.soc.v10i2.23915

Sabedot, S., \& Pereira Neto, T. J. (2017). Desempenho ambiental dos catadores de materiais recicláveis em Esteio (RS). Engenharia Sanitária e Ambiental, 22(1), 103-109. https://doi.org/10.1590/S1413-41522016155686

Santiago, L. S., \& Dias, S. M. F. (2012). Matriz de indicadores de sustentabilidade para a gestão de resíduos sólidos urbanos. Engenharia Sanitária e Ambiental, 17(2), 203-212. https://doi.org/10.1590/S141341522012000200010

Selur. Sindicato das Empresas de Limpeza Urbana do Estado de São Paulo. (2020). Índice de sustentabilidade da limpeza urbana - ISLU. Retrieved from https://selur.org.br/publicacoes/indice-de-sustentabilidade-dalimpeza-urbana-islu-edicao-2020/ 
Seplag. Secretaria De Planejamento E Gestão De Minas Gerais. (2015). Plano mineiro de desenvolvimento integrado 2016-2027 (Vol. 3). Belo Horizonte: Seplag.

Silva, C. L., Fugii, G. M., \& Santoyo. A. H. (2017). Proposta de um modelo de avaliação das ações do poder público municipal perante as políticas de gestão de resíduos sólidos urbanos no Brasil: um estudo aplicado ao município de Curitiba. Revista Brasileira de Gestão, 9(2), 276-292. https://doi.org/10.1590/21753369.009.002.AO09

Snis. Sistema Nacional De Informações Sobre Saneamento. (2019). $17^{\circ}$ Diagnóstico do manejo de Resíduos Sólidos Urbanos 2018. Brasília: Secretaria Nacional de Saneamento do Ministério do Desenvolvimento Regional.

Snis. Sistema Nacional De Informações Sobre Saneamento. (2020). Série história. Retrieved from http://app4.mdr.gov.br/serieHistorica/.

Zaros. L. G., \& Medeiros. H. R. (2011). Bioestatística (2nd ed). Edufrn: Natal.

\section{Copyrights}

Copyright for this article is retained by the author(s), with first publication rights granted to the journal.

This is an open-access article distributed under the terms and conditions of the Creative Commons Attribution license (http://creativecommons.org/licenses/by/4.0/). 